Лігоцький Анатолій Олексійович доктор педагогічних наук, професор, тел.: (067) 445-28-41, e-mail: kafedra777@ukr.net, https://orcid.org/0000-0001-93264707

Пасько Анастасія Анатоліївна магістр із педагогіки, тел.: (066) 210-93-92, e-mail: ovdienko95n@gmail.com, https://orcid.org/0000-0002-6218-0663

\title{
КВАЛІФІКАЦІЯ ПЕРСОНАЛУ ДОШКІЛЬНОГО НАВЧАЛЬНОГО ЗАКЛАДУ ТА ЙОГО ВАЖЛИВІСТЬ ДЛЯ СОЦАЛІЗАЦІї ДИТИНИ У СВІТИ
}

Анотація. Встановлено, що дошкільна освіта - необхідна база для соціалізації дитини у світі та її успішного навчання в школі. Головний критерій якості дошкільної освіти - бажання дитини самостійно надалі вивчати та пізнавати світ, а також створені в дитсадку належні умови для розвитку та росту дитини. Але часто батьки стикаються 3 проблемою, коли вони не отримують належну якість навчання для своєї дитини (навіть, коли платять за це немаленькі гроші. Дошкільна освіта є обов'язковою первинною складовою частиною системи безперервної освіти в Україні - сукупності навчально-виховних закладів, призначених для цілеспрямованого навчання i виховання. Ї̈̈ функціонування регламентоване Конституцією України, законами України «Про освіту», «Про дошкільну освіту», «Про охорону дитинства», Конвенцією ООН про права дитини.

Проведений аналіз предметного поля дослідження теми дипломної роботи свідчить, що ошкільна освіта сприяє реалізації прав дитини, закріплених законодавчими міжнародними документами, зокрема права на охорону здоров'я, права на освіту, права на участь в іграх, права на збереження своєї індивідуальності, права на захист від усіх форм фізичного, психічного насильства, приниження, зловживання, відсутності турботи чи недбалого i грубого поводження.

Проаналізовано, що принципи державної політики у галузі освіти відображені у Законі України «Про освіту» (1996), який проголошує освіту пріоритетною сферою соціально-економічного, духовного і культурного розвитку суспільства. Основними принципами освіти в Україні є:

- доступність для кожного громадянина усіх форм і типів освітніх послуг, що 
надаються державою;

- рівність умов кожної людини в реалізації іiі здібностей, таланту, у всебічному розвитку;

- гуманізм, демократизм, пріоритетність загальнолюдських духовних цінностей;

- органічний зв'язок зі світовою і національною історією, культурою, традиціями;

- незалежність від політичних партій, громадських і релігійних організацій;

- науковий, світський характер, інтеграція 3 наукою i виробництвом, взаємозв'язок з освітою інших країн;

- гнучкість і прогностичність, єдність і наступність;

- безперервність і різноманітність;

- поєднання державного управління і громадського самоврядування в освіті.

Ключові слова: дошкільна освіта, суспільне виховання, рання обдарованість, забезпечення умов для розвитку талановитих дітей, суспільне дошкільне виховання.

Ligotskiy Anatoly Oleksiyovich Doctor of Pedagogy, Professor, tel.: (067) 44528-41, e-mail: kafedra777@ukr.net, https://orcid.org/0000-0001-9326-4707

Pasko Anastasia Anatoliyivna Master of Pedagogy, tel.: (066) 210-93-92, e-mail: ovdienko95n@gmail.com, https://orcid.org/0000-0002-6218-0663

\section{QUALIFICATION OF PRESCHOOL EDUCATIONAL STAFF AND ITS IMPORTANCE FOR CHILD'S SOCIALIZATION IN THE WORLD}

Abstract. It has been established that preschool education is a necessary base for the socialization of a child at a meeting and a successful education in school. The main criterion for the quality of preschool education is that the child's self-indulgence is selfconscious and educated, as well as for the child's growth and growth. But often the daddy stuck with the problem, if the stench doesn't take in the proper quality of the present for his child (navit, if you pay for the price of a rather big penny. The functions of the Constitution of Ukraine, the laws of Ukraine "About education", "About preschool education", "About the protection of children", the UN Convention on the Rights of the Child.

Conducting an analysis of the subject field before the completion of those diploma robots to demonstrate that the education of the child's rights, enshrined in legislative international documents, the right to protect health, the right to educate, the right to 
participate in the right to participate from the most common forms of physical, mental violence, humiliation, ominousness, in the presence of turbulence, not bad and rude harassment.

It has been analyzed that the principle of state policy in the galuzy of the vision of the Law of Ukraine "On Education" (1996), which will talk about the priority sphere of the social-economic, spiritual and cultural development of the suspension. The main principles of education in Ukraine are:

- $\quad$ accessibility for the skin bulk of the best forms and types of holy services, which can be relied upon by the power;

- $\quad$ parity of the minds of the skin people in the implementation of the health, talent, and universal development;

- $\quad$ humanism, democracy, the priority of the spiritual values of the country;

- $\quad$ organic connection with light and national history, culture, traditions;

- $\quad$ independence of political parties, community and religious organizations;

- scientific, svitsky character, integration with science and virobnity, interconnection with the sanctuary of the world;

- $\quad$ dullness and predictability, monotony and onset;

- $\quad$ reliability and versatility;

- $\quad$ day of the sovereign government and the huge self-assembly in the light.

Keywords: preschool education, supportive education, early endowment, preservation of minds for the development of talented children, supportive preschool education.

Постановка проблеми. На сучасному етапі розвитку суспільства проблема психолого-педагогічної науки і практики не лише у відсутності теоретичних, методологічних, методичних, управлінських напрацювань для розв'язання проблем дошкільної освіти, а й у необхідністі модернізації існуючих та пошуку нових підходів до формування особистісно орієнтованої моделі виховання. Сьогодні людство опинилося перед принципово новими цивілізаційними викликами, які потребують відповідних знань, внутрішньої готовності особистості, уміння адекватно оцінювати ситуацію і діяти. Державна політика у цій сфері орієнтує на обов'язковість дошкільної освіти, гуманізацію педагогічного процесу, створення сприятливих умов для розвитку дітей, забезпечення єдності роботи батьків, дошкільного закладу, громадськості у їхньому вихованні, оновлення змісту підготовки педагогічних кадрів, удосконалення умов фінансування дошкільного виховання та управління.

Аналіз останніх досліджень та публікацій. Проблеми дошкільної освіти досліджувалися В. Гарбичем, О. Мельником, С. Осадчим, М. Піддячим, 
В. Хільковцем. У роботах П. Атутова, В. Сидоренка, М. Тименка, М. Янцура. У роботах авторів розкрито особливості тенденцій дошкільної освіти в Україні. Слід зазначити, що якщо у попередні роки в основному досліджувалися проблеми, пов'язані розвитком індивідуальності кожної дитини, то в останній час чільне місце посідає вивчення проблем психолого-педагогічні теорії про розвиток та виховання дітей дошкільного віку Я. А. Коменського, Ф. Фребеля, Жана-Овіда Декролі, Марії Монтессорі. На особливу увагу заслуговує Вальдорфська педагогіка, як своєрідна цілісна концепція виховання i навчання дітей, автором якої $\epsilon$ австрійський учений і філософ Р. Штайнер.

Мета статті теоретичне узагальнення i нове вирішення науковотеоретичного завдання 3 виявлення нових тенденцій і закономірностей розвитку персоналу дошкільного навчального закладу для формування особистісно орієнтованої моделі виховання.

Виклад основного матеріалу. Керуючись Законом України «Про дошкільну освіту», адміністрація дошкільного навчального закладу приймає на роботу тільки педагогів, які мають відповідну повну вищу та неповну вищу педагогічну освіту. Дошкільний навчальний заклад повністю укомплектований педагогічними кадрами та обслуговуючим персоналом.

Підбір і розстановка педагогічних кадрів має велике значення як у роботі 3 дітьми так і в роботі колективу в цілому. При комплектації груп педагогічними працівниками намагаємось враховувати психологічну сумісність педагогів, рівень їх професіоналізму, досвід роботи, ділові якості [1].

Вихователь - це не професія, це покликання, спосіб життя і стан душі. Він повинен не просто любити возитися з дітьми, а проживати разом 3 ними їхні маленькі життя. Батьки залишають своїх рідних, беззахисних діток на чужих тіткою і забирають тільки ввечері, при цьому потрібно бути впевненими, що діти не просто під наглядом, а знаходяться в теплих надійних руках вихователя. Якими якостями повинен володіти вихователь, яким він має бути в нинішній час, як він повинен поводитися з вихованцями, щоб батьки довіряли йому на $100 \%$, а дітки 3 усмішками бігли в дитячий сад?

Яким повинен бути вихователь? Перше, що спадає на думку, дитяча пісенька: "Від посмішки стане всім світліше ...". Якщо вихователь зустрічає дитинку і проводжає маму з посмішкою, то і мама, i дитина з задоволенням розлучаться, малюк з радістю побіжить в групу, а мама в піднесеному настрої відправиться на роботу. Вихователь повинен бути комунікабельним, він повинен 3 легкістю знаходити спільну мову, не тільки з дітьми, але і з батьками [2; 3].

У хорошого вихователя завжди позитивна атмосфера в колективі, дітки дружні, а батьки чуйні. Звичайно ж, вихователь - це не просто гарна тітка, це, перш за все педагог, він повинен допомагати батькам у вихованні дитини, тому 
зайва доброта тут ні до чого. Вихователь повинен бути чуйним, чуйним, завжди готовим допомогти і почути, але й у міру строгим він теж бути зобов'язаний, інакше порядку в колективі не буде.

Зараз вимоги до вихователя дуже високі і багато батьків зовсім не знають, яким має бути сучасний вихователь? Крім усього перерахованого вище, на думку багатьох, сучасний вихователь, повинен бути творчою особистістю. Крім вищої педагогічної освіти, він повинен вміти: танцювати, співати, малювати, знати кілька різних розвиваючих методик, для діток дошкільного віку. Всі ці знання повинні застосовуватися на заняттях у дитячому садку. Потрібно пам'ятати, що професія вихователь - це виховно-освітня робота і головне завдання вихователя, перш за все, це всебічний розвиток дитини, формування у нього різноманітних навичок, правил поведінки, доступних знань, підготовка малюка до школи [4].

Після вищесказаного, стає зрозумілим, яким повинен бути вихователь дошкільного навчального закладу. Потрібно розуміти, що в різні періоди розвитку суспільства, перед вихователями ставляться все нові й нові завдання, але головна, залишається завжди - розвиток всебічно розвиненої, фізично здорової особистості. Суспільство змінюється, змінюються дітки, потрібно розуміти, що вони не стають краще або гірше - вони просто інші. А головне завдання вихователя - розуміти дітей.

В дитячому садку малюки проводять повноцінний день 3 прийомами їжі, прогулянками, сном, навчально-розвиваючими заняттями i гігієнічними процедурами. Відповідно, задовольнити потреби всіх членів однієї групи i організувати їх злагоджену діяльність в кожному 3 процесів одна людина (вихователь) просто не здатний. Саме тому й була введена посада помічника вихователя, альтернативні назви якої - молодший вихователь, няня, - у побуті [5; 6].

Помічник вихователя повинен забезпечувати чистоту в приміщеннях, виділених групі, і проводити необхідні заходи, спрямовані на досягнення цієї мети відповідно до графіку, встановленого в установі. Щодня повинна проводитися вологе прибирання їдальні, спальні, ігровий зон, а також коридору та інших приміщень, займаних групою, - i це обов’язок няні. Важлива умова: прибирати категорично забороняється в присутності дітей. Помічник вихователя обов'язку має різні, серед них також допомогу в сервіровці столу перед трапезами, прибирання в їдальні після прийомів їжі, миття посуду.

Також нянечка допомагає вихователю стежити за особистою гігієною дітей, вмиває і підмиває їх при необхідності, допомагає переодягати.

Помічник вихователя обов'язки має різноманітні, але при цьому нянечка також повинна бути завжди готова прийти на допомогу вихователю або навіть замінити його на деякий час.

Відповідно, в обов’язки цього працівника входить допомога в організації 
дозвілля, навчальних занять та інших заходів. Крім того, помічник вихователя на прохання вихователя супроводжує групу на прогулянці.

Також цей співробітник повинен допомагати переодягати дітей (у тому числі при організації прогулянок або під час підготовки до сну і після нього). Якщо вихователь запрошується на якісь заходи завідуючої дошкільного закладу, його помічник повинен його замінити і забезпечити порядок у групі, а також зайняти вихованців згідно розпорядку дня [7].

Для визначення потреби закладу в персоналі потрібно з’ясувати, під впливом яких факторів вона формується. Оскільки дошкільний навчальний заклад №19 є відкритою соціальною системою, його потреби в персоналі обумовлюються стратегією його розвитку, на яку впливає велика кількість як внутрішніх, так і зовнішніх факторів.

Внутрішні фактори - це, перш за все, цілі закладу, для реалізації яких потрібен персонал. При чітко визначеній цілі значно легше визначити потребу в персоналі, оскільки потреби не змінюються протягом довгого періоду. I навпаки, при зміні цілей — перехід на нові технології - потреба в якісному персоналі змінюється. Одним з напрямків змін потреби організації в персоналі $є$ [8]:

- внутрішньоорганізаційна динаміка робочої сили;

- звільнення за власним бажанням;

- вихід на пенсію;

- декретні відпустки тощо.

Вкрай важливо відслідковувати цю динаміку i прогнозувати зміни. Зовнішні фактори. Серед великої їх кількості існує кілька найбільш важливих, що безпосередньо впливають на стан ринку праці - джерела робочої сили для більшості закладів, темпи зростання і рівень інфляції, структурні зміни, розвиток технологій, політичні зміни, конкуренція та стан освітнього ринку [9].

Відслідковування і знання динаміки факторів, які впливають на потреби в персоналі, є основою іï планування. У кожний даний момент заклад повинен вирішувати питання: в якому підрозділі, яку загальну кількість працівників і якої кваліфікації потрібно мати для забезпечення ефективного освітнього процесу. Після чого визначається потреба в персоналі.

Наймання працівників здійснюється на основі штатного розкладу. Основними методами прогнозування потреби в робочій силі є: економетричний, за допомогою якого потреба в персоналі виводиться 3 передбачуваних рівнів кінцевого попиту на товари та послуги на певний рік у майбутньому.

Екстраполяція - найбільш простий метод, який часто використовується, суть якого полягає в перенесенні минулих тенденцій, змін у величині сукупної робочої сили та їі структури на майбутнє. Позитивною стороною є те, що він доступний. Негативна сторона - неможливість врахувати зміни розвитку 
організації i зовнішнього середовища. Тому цей метод підходить для короткотермінового планування i для організації зі стабільною структурою i стабільним зовнішнім середовищем. Багато закладів користуються методом скорегованої екстраполяції, при якому враховуються зміни в співвідношенні факторів, що визначають кількість працівників, підвищення продуктивності праці, зміни цін тощо $[10 ; 11]$.

Метод експертних оцінок- це метод, що грунтується на використанні думки спеціалістів для визначення потреб у персоналі. Цими спеціалістами $\epsilon$ керівники підрозділів. Залежно від розмірів закладу i кількості лінійних керівників проводять групове обговорення або письмовий огляд (кожному працівнику пропонується відповісти на ряд питань). Перевага цього методу - в залученні лінійних керівників з їх досвідом, знаннями, що дозволяє більш точно визначити потребу в кількісному й якісному вимірі.

Метод трудових балансів - метод, що відслідковує рух робочої сили, використання фонду часу і грунтується на взаємозв’язку ресурсів, які потрібні закладу в рамках планового періоду.

Для визначення потреб у спеціалістах на термін до 5 років використовується штатно-номенклатурний метод, який грунтується на показниках розвитку, типових структурах і штатах, а також номенклатурах посад, які повинні займати спеціалісти з вищою та середньо-спеціальною освітою. Назви посад і рівень освіти в номенклатурі вказуються відповідно до Кваліфікаційного довідника посад керівників, спеціалістів і службовців, а назви спеціальностей згідно з діючим переліком спеціальностей.

Процес планування має своє логічне завершення в плані. План - це офіційний документ, в якому сконцентрована система взаємопов'язаних показників прогнозу розвитку організації для досягнення поставленої мети.

Залежно від тривалості планового періоду, цілей та умов планування розрізняють три види планування:

- стратегічне (перспективне);

- $\quad$ тактичне (середньострокове) таблиця;

- поточне (оперативне).

На стратегічному рівні визначають довгострокові, розраховані на 10 - 15 років цілі закладу, напрямки його розвитку, враховуючи загальну ситуацію на ринку праці, тенденції розвитку дошкільної освіти, концепції і напрямки розвитку освіти в цілому. Встановлюються ресурси, необхідні для досягнення цілей закладу. Обирається метод (стратегія) досягнення цих цілей. Оформлюють результати стратегічного планування у вигляді концепцій i програм розвитку, протоколів намірів $[12 ; 13 ; 14 ; 15]$. 
На тактичному рівні загальні цілі конкретизуються на коротший період - 2-5 років, і відповідно до поставлених завдань залучаються необхідні ресурси. Строк у 2-5 років зумовлений тим, що він співвідноситься із тривалістю проектування й освоєння нових технологій, розв'язку масштабних задач по розвитку закладу.

Висновки. Таким чином, дошкільна освіта сприяє реалізації прав дитини, закріплених законодавчими міжнародними документами, зокрема права на охорону здоров'я, права на освіту, права на участь в іграх, права на збереження своєї індивідуальності, права на захист від усіх форм фізичного, психічного насильства, приниження, зловживання, відсутності турботи чи недбалого i грубого поводження.

\section{Jimepamypa:}

1. Лордкипанидзе Д.О., Педагогическое учение К.Д. Ушинского. - М.: «Педагогика», 1954.

2. Мухина В.С. Детская психология. - М., 1985.

3. Песталоцци И.Г., Избранные педагогические сочинения в 3-х томах, Т.3, М., 1961-1965.

4. Підкурганна Г.О., Артемова Л.В., Орланова Н.П. Концепція дошкільного виховання в Україні. - К.: МНО, 2012.

5. Развитие познавательных способностей в процессе дошкольного воспитания / Под ред. Л.А. Венгер. - М.: «Педагогіка», 2018.

6. Содержание и методы умственного воспитания дошкольников / Под ред. Н.Н. Поддьякова. - М.: «Педагогика», 2017.

7. Соловьева Г. Что такое педагогическая система Монтессори? // Первое сентября. 2010.- №1.- c.6.

8. Тихеева Е.И. Развитие речи детей. - М.: «Просвещение», 2010.

9. Усова А.П., Обучение в детском саду. - М.: «Просвещение», 2016.

10. Ушинский К.Д. Избранные педагогические сочинения в двух томах/ Под редакцией А.И. Пискунова, Г.С. Костюка, Д.О. Лордкипанидзе, М. Шабаевой. Т.1. - М.: «Педагогика», 2013.

11. Фребель Ф. Будем жить для своих детей / Сост. и пред. Л.М. Волобуева. - М.: «Карапуз», 2013.

12. Эльконин Д.Б. Психология игры. - М.: «Педагогика», 2009.

13. Базова програма розвитку дитини дошкільного віку “Я у світі"/ Міністерство освіти і науки України, Академія пед. наук України ; наук. ред. та упор. О. Л. Кононко. - К. : Світич, 2018. - $430 \mathrm{c}$.

14. Romanenko E. Chaplai I. PUBLIC ADMINISTRATION BY THE MODERN INFORMATION TECHNOLOGIES IN CONSTRUCTION OF UKRAINE / I. Chaplay // Публічне урядування. - 2017. - №2 (7) - травень 2017. - С. 172-180.

15. Romanenko E. Chaplai I., Hurkovskyy V. THEORETICAL AND METHODOLOGICAL IDENTIFICATION OF THE CONCEPT OF "MARKETING COMMUNICATIONS" (ARCHETYPAL APPROACH) / $\quad$ E. Romanenko, I. Chaplay, Hurkovskyy V. // Публічне урядування. - 2017. - №3 (8) -червень 2017 (спецвипуск). - С. 259-266.

\section{References:}

1. Lordkipanidze D.O., Pedagogicheskoe uchenie K.D. Ushinskogo. - M.: «Pedagogika», 1954. 
2. Muhina V.S. Detskaja psihologija. - M., 1985.

3. Pestalocci I.G., Izbrannye pedagogicheskie sochinenija v 3-h tomah, T.3, M., 1961-1965.

4. Pidkurganna G.O., Artemova L.V., Orlanova N.P. Koncepcija doshkil'nogo vihovannja v Ukraïni. - K.: MNO, 2012.

5. Razvitie poznavatel'nyh sposobnostej $\mathrm{v}$ processe doshkol'nogo vospitanija / Pod red. L.A. Venger. - M.: «Pedagogika», 2018.

6. Soderzhanie i metody umstvennogo vospitanija doshkol'nikov / Pod red. N.N. Podd'jakova. M.: «Pedagogika», 2017.

7. Solov'eva G. Chto takoe pedagogicheskaja sistema Montessori? // Pervoe sentjabrja. - 2010.№1.- s.6.

8. Tiheeva E.I. Razvitie rechi detej. - M.: «Prosveshhenie», 2010.

9. Usova A.P., Obuchenie v detskom sadu. - M.: «Prosveshhenie», 2016.

10. Ushinskij K.D. Izbrannye pedagogicheskie sochinenija $\mathrm{v}$ dvuh tomah/ Pod redakciej A.I. Piskunova, G.S. Kostjuka, D.O. Lordkipanidze, M. Shabaevoj. T.1. - M.: «Pedagogika», 2013.

11. Frebel' F. Budem zhit' dlja svoih detej / Sost. i pred. L.M. Volobueva. - M.: «Karapuz», 2013.

12. Jel'konin D.B. Psihologija igry. - M.: «Pedagogika», 2009.

13. Bazova programa rozvitku ditini doshkil'nogo viku "Ja u sviti"/ Ministerstvo osviti i nauki Ukraïni, Akademija ped. nauk Ukraïni ; nauk. red. ta upor. O. L. Kononko. — K. : Svitich, 2018. — $430 \mathrm{~s}$.

14. Romanenko E. Chaplai I. PUBLIC ADMINISTRATION BY THE MODERN INFORMATION TECHNOLOGIES IN CONSTRUCTION OF UKRAINE / I. Chaplay // Publichne urjaduvannja. - 2017. - №2 (7) - traven' 2017. - S. 172-180.

15. Romanenko E. Chaplai I., Hurkovskyy V. THEORETICAL AND METHODOLOGICAL IDENTIFICATION OF THE CONCEPT OF "MARKETING COMMUNICATIONS" (ARCHETYPAL APPROACH) / E. Romanenko, I. Chaplay, Hurkovskyy V. // Publichne urjaduvannja. - 2017. - №3 (8) -cherven' 2017 (specvipusk). - S. 259-266. 